\title{
PERGESERAN PADA KATA PINJAMAN BAHASA ARAB DI KOMUNITAS ARAB
}

\author{
Adisti Nur Inayah Nisa ${ }^{1}$, I Made Suastra ${ }^{2,}$ I Ketut Darma Laksana ${ }^{3}$ \\ Universitas Udayana \\ Email: nadisti@gmail.com
}

\begin{abstract}
Abstrak
Penelitian ini bertujuan untuk mengetahui pergeseran bahasa Arab di kampung Arab yang mana lebih difokuskan pada kata pinjaman.Teori yang digunakan yaitu Teori language borrowing yang dikemukakan oleh Eunar Haugen. Metode dan teknik pengumpulan data menggunakan metode simak dengan teknik yang digunakan yaitu teknik rekam, simak libat cakap dan catat dan teknik pancing. Metode dan teknik analisis data menggunakan metode kualitatif dan interpretasi. Metode dan teknik penyajian hasil analisis data menggunakan metode formal dan informal. Hasil penelitian yaitu, ditemukan kata pinjaman dalam bahasa Arab sesuai dengan teori eunar haugen. Kategori pertama yaitu analisis mengenai loan word, dalam bahasa Arab ditemukan kata pinjaman loanword, yaitu:أمي , أبي (abi) (ummi), هدية (2hadiyah), , زحسن (zaujah), (ahsan) sedangkan loanshift terbagi menjadi tiga yaitu loan homonym, sinonimdan translation. Adapun contoh loan homonym yaitu: هوي (hawi), فضول (fudhul), شغل (syughul), loan sinonim yaitu: عغوا

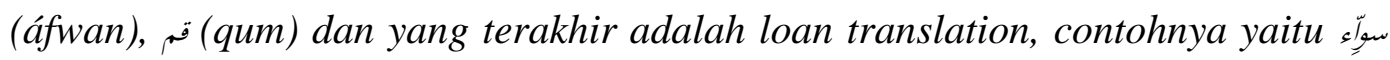
(sawak) Dan yang terakhir pinjaman yang termauk loanblend adalah رجل (rijal), يس (yasin), بيس (kahwah), بيت (bait). Kesimpulannya yaitu pergeseran bahasa ini bisa terjadi dikarenakan adanya pengaruh dialek buleleng selain itu juga, pengaruh bahasa Indonesia juga sangat besar untuk merubah kosa-kata dalam bahasa Arab.
\end{abstract}

Kata kunci: pergeseran bahasa, kata pinjaman, bahasa Arab

\section{PENDAHULUAN}

Komunitas Arab merupakan salah satu komunitas yang cukup berkembang di Indonesia. Banyaknya komunitas Arab yang mendiami daerah-daerah di Indonesia dan cirri khas mereka yaitu menguasai pusat perdagangan di Indonesia membuat mereka cukup terkenal di kalangan masyarakat Indonesia.

Komunitas Arab masuk ke Indonesia pada tahun 1900 dengan tujuan utama berdagang dan menyebarkan agama Islam. Demi terlaksananya tujuan mereka, maka komunitas Arab pun mulai mempelajari Bahasa Melayu yang pada saat itu memang menjadi bahasa utama 
masyarakat Indonesia. Komunitas Arab dengan cepat menyesuaikan diri dengan warga setempat sehingga semakin lama maka komunitas Arab mulai sedikit demi sedikit melupakan bahasa mereka yaitu bahasa Arab.

Ketika mereka mengangap bahasa setempat adalah bahasa komunikasi yang memudahkan mereka dalam berbaur dengan masyarakat setempat, maka komunitas Arab mulai mencari bahasa yang mereka anggap dinamis dan strategis sehingga bahasa Arab yang pada awalnya menjadi bahasa utama mereka sedikit demi sedikit mulai mereka lupakan dan bergeser menjadi bahasa di daerah yang mereka tinggali. Menurut Sumarsono (1992; 230) pergeseran bahasa berarti, suatu guyup (komunitas) meninggalkan suatu bahasa sepenuhnya untuk memakai bahasa lain. Bila pergeseran suatu bahasa sudah terjadi, para warga guyup itu secara kolektif memilih bahasa baru. Dalam pemertahanan bahasa, guyup itu secara kolektif menentukan untuk melanjutkan memakai bahasa yang sudah biasa dipakai. Ketika guyup tutur mulai memilih bahasa baru di dalam ranah yang semula diperuntukkan bagi bahasa lama, itulah mungkin merupakan tanda bahwa pergeseran sedang erlangsung.

Pergeseran tidak hanya terjadi di kalangan komunitasnya saja, tetapi juga terjadi pada bahasa pinjaman bahasa Arab yang digunakan oleh komunitas Arab. Banyak komunitas Arab tetap menggunakan leksikon bahasa Arab dalam tuturan mereka, sehingga banyak ditemukan pergeseran unsure-unsur pinjaman pada leksikon bahasa Arab. Menurut Haugen,

borrowing is the process of importing linguistic items from one linguistic system into another that occurs any time when two cultures are in contact over a period of time. Menurut Haugen Dalam tuturannya, dapat ditemukan leksikon-leksikon bahasa Arab yang telah mengalami perubahan, sehingga perubahan tersebut akan dibahas memakai teori language borrowing oleh Eunar Haugen.

\section{TINJAUAN PUSTAKA}

Berdasarkan data yang diperoleh dari studi pustaka ditemukan beberapa hasil penelitian yang berkaitan dengan penelitian ini. Ferguson (Fishman, 1968: 375-381) dalam penelitiannya mengupas tentang kebanggaan serta sikap bahasa para penutur bahasa Arab terhadap bahasanya.Nader (1962) menulis tentang A Note an Attitudes and The Use of Language, (Fishman, 1968: 276-281). Dalam tulisan tersebut dideskripsikan tentang perbandingan dialek bahasa Arab menurut strata sosial pada masyarakat Libanon, dan pada 
akhir tulisannya disimpulkan bahwa kekaguman terhadap suatu ragam tidak dipengaruhi kemakmuran penuturnya.

Altoma (1969) dalam bukunya The Problem of Diglosia in Arabic: A Comparative Study of Classical and Iraqi Arabic, mengorientasikan tulisannya pada deskripsi sinkronis bahasa Arab dialek Iraq. Pada tahap awal dideskripsikan karakteristik bahasa Arab dialek Iraq yang diperoleh dengan membandingkan dengan bahasa Arab klasik.Dari perbandingan tersebut, diperoleh variasi fonologi, system pembentukan nomina dan verba, system sintaksis, dan diakhiri dengan deskripsi pembentukan leksikon bahasa Arab dialek Iraq.

Jiah Fauziyah (2006) mengkaji tentang unsur - unsur bahasa Arab dalam komunikasi masyarakat keturunan Arab Surakarta. Karya tersebut mengupas tentang wujud serta fitur khas yang dimiliki bahasa Arab Surakarta, meliputi fitur fonologi, morfologi, gramatikal, dan leksikal. Penggunaan unsur - unsur bahasa Arab dalam komunikasi para penuturnya juga tidak luput dari perhatian, di mana bahasa Arab Surakarta digunakan untuk menunjukkan rasa solidaritas antar etnis Arab Surakarta dan penggunaan unsur - unsur tersebut dilatarbelakangi oleh tujuan-tujuan tertentu, seperti penegasan, merahasiakan suatu pesan dari pendengan yang lain. Diakhiri dengan eksplorasi tentang sejauh mana bahasa Arab komunitas Surakarta dipertahankan oleh para penuturnya. Penelitian tersebut berakhir dengan kesimpulan bahwa bahasa Arab komunitas Surakarta cenderung mengalami pergeseran. Pergeseran tersebut tidak hanya dalam hal menghilangnya beberapa fitur bahasa Arab standar. Akan tetapi, pada ditinggalkannya bahasa Arab Surakarta oleh penuturnya kepada bahasa Indonesia ataupun bahasa Jawa.

Fuad (2008) juga meneliti hal yang sama dengan Jiah Fauziyah yaitu hubungan antara bahasa dan etnik yang terjadi dalam komunitas Arab di Kampung Arab Pamekasan. Penelitian ini berangkat dari asumsi bahwa, ada kecenderungan penggunaan sebuah bahasa sebagai sikap untuk menjaga dan mempertahankan identitas kelompok tertentu dan juga untuk menunjukkan eksistensi etnik dalam masyarakat multilingual. Penelitian ini menjawab tiga persoalan besar, yaitu 1) wujud bahasa Arab di kampung Arab Pamekasan 2) penggunaan bahasa Arab dalam komunikasi 3) sejauh mana bahasa Arab dipertahankan oleh penuturnya. Dalam pembahasan masalah pertama yang meliputi ciri fonologis, morfologis, sintaksis, dan leksikon. Untuk memecahkan keempat persoalan itu, digunakan analisis perbandingan ala Neogrammarian, yaitu dengan membandingkan leksikon bahasa Arab yang ada di kampung Arab Pamekasan 
dengan bahasa Arab standar. Dari perbandingan tersebut diperoleh kecenderungan untuk memodifikasi fonem-fonem bahasa Arab standar ke bahasa Arab Pamekasan yang berimbas pada hilangnya sebagian fonem khas yang dimiliki bahasa Arab standar. Masuknya fitur lingual bahasa Madura dan bahasa Indonesia ke dalam kaidah morfologis maupun sintaksis sebagai akibat dari kontak bahasa yang berlangsung sekian lama. Pembahasan persoalan kedua adalah untuk menjawab bagaimana strategi penggunaan bahasa Arab dalam komunikasi. Guna memecahkan persoalan tersebut digunakan pendekatan etnografi komunikasi untuk mengetahui pola penggunaan bahasa Arab Pamekasan dalam komunikasi. Dari analisis tersebut dihasilkan bahwa bahasa Arab Pamekasan digunakan dalam mekanisme alih kode, baik situasional maupun nonsituasional. Bahasa Arab Pamekasan dipilih sebagai kode oleh seorang penutur dengan mempertimbangkan mitra tutur, media tutur, situasi tutur, dan tujuan tutur yang hendak dicapai. Pembahasan persoalan ketiga adalah untuk menjawab sejauh mana bahasa tersebut dipertahankan oleh para penuturnya. Guna menjawab pertanyaan tersebut, digunakan berbagai isntrumen penentu yang nantinya akan menunjukkan pemertahanan maupun pergeseran bahasa. Dari perbandingan tersebut bahwa bahasa Arab di kabupaten Pamekasan cenderung bertahan, hal tersebut didukung oleh sikap kaum remaja sebagai bahasa yang dapat menyatukan mereka dalam ikatan persaudaraan. Sikap akomodatif masyarakat komunitas Madura Pamekasan yang turut menggunakan bahasa Arab Pamekasan sebagai pilihan kode dalam komunikasi mereka juga menjadi faktor yang menjadikan bahasa Arab Pamekasan tetap eksis sampai saat ini.

Saifuddin Ahmad Husin (2009) juga melakukan penelitian yang bertemakan pemakaian bahasa Arab oleh masyarakat Arab dengan mengambil lokasi di daerah Martapura Kabupaten Banjar. Adapun permasalahan yang diangkat yaitu mengenai struktur bahasa Arab yang dipakai oleh anggota masyarakat di Martapura, kemudian peran berbagai macam kode yang menjadi khasanah bahasa para anggota masyarakat, faktor sosial dapat menentukan terjadinya alih kode dan campur kode dan yang terakhir yaitu faktor-faktor yang menjadikan bahasa Arab masih digunakan hingga saat ini. Teori yang digunakan adalah teori keragaman bahasa Arab (Struktur bahasa Arab Fusha, Dialek-dialek bahasa Arab, variasi Fonologis, Variasi Morfologis dan Sintaksis, dan bahasa Arab dialek Yaman/Hadhramaut), bahasa Arab di Indonesia (Bahasa Ara sebagai bahasa agama, bahasa Arab sebagai jargon dagang), konsep 
Sosiolinguistik (berisi sub bahasan tentang Bilingualisme, Alih kode dan campur kode, adaptasi dan akomodasi, perubahan bahasa, kontak bahasa, interferensi, interferensi bunyi, interferensi gramatikal dan leksikal, pijin dan kreol, pergeseran dan pemertahanan bahasa, bahasa dan etnisitas, dan etnografi komunikasi).

\section{KERANGKA TEORI}

\subsection{Teori Pinjaman Bahasa}

Kata pinjaman adalah cara lain untuk menambahkan kosa kata baru pada bahasa (Wardhaugh, 1972). Pinjaman bahasa adalah istilah teknis untuk penggabungan item dari satu bahasa ke bahasa lain (Mesthrie, 2000). Menurut Jendra ( 2010, 20) Ada tiga kelompok dasar pinjaman:
○ Kata pinjaman
- Campuran pinjaman
- Pergeseran pinjaman

Kata - kata pinjaman dibedakan lebih lanjut ke dalam dua jenis, yaitu kata - kata pinjaman yang diperlukan atau tidak perlu. Kata - kata pinjaman yang diperlukan, juga bernama impor, adalah kata - kata yang dipinjam dari bahasa asing karena mereka menemukan tidak ada kata yang tepat dalam bahasa mereka sendiri yang dapat mengungkapkan apa yang mereka maksud. Kata - kata pinjaman yang tidak perlu adalah kata - kata dari bahasa asing yang dipinjam meskipun ada kata yang benar - benar sesuai dengan kata dalam bahasa penerima yang dapat digunakan sebagai pengganti (Jendra, 2010).

Istilah Borrowing yang pernah dikemukakan oleh Bloomfield (1933: 509-566) yang diterjemahkan dengan pinjaman yang apabila diberi pengertian:” pemasukan unsurfonologis, grammatical atau leksikal dalam bahasa atau dialek dari bahasa atau dialek lain karena kontak atau peniruan; hasil prose situ disebut pinjaman “. Satuan lingual dari pinjaman itu disebut unsur pinjaman. Haugen (1950) menyatakan bahwa ada tiga kategori pinjaman bahasa diantaranya loanwords (pemasukan morfemis tanpa substitusi), loanblends (substitusi morfemis sekaligus pemasukan), dan loanshifts (substitusi morfemis tanpa pemasukan)

\subsubsection{Loanwords (Pemasukan Morfemis tanpa Substitusi)}

Salah satu terpenting dari teori Haugen adalah loanwords (pemasukan morfemis tanpa substitusi). Loanwords menunjukkan penambahan morfem tanpa adanya penggantian, tetapi dengan beberapa tingkat dari penggantian secara fonologi. 
Dengan kata lain, sebuah bahasa meminjam baik dari segi bentuk maupun makna dari sebuah kata asing yang mana melalui proses secara fonetik pada struktur bahasa pengguna. Jadi dapat disimpulkan bahwa loanwords (pemasukan morfemis tanpa substitusi) adalah proses peminjaman bahasa tanpa adanya perubahan dalam leksikonnya.

\subsubsection{Loanblends (Substitusi Morfemi sekaligus Pemasukan)}

Kategori yang terpenting kedua dari teori Haugen adalah loanblends (substitusi morfemis sekaligus pemasukan). Maksud dari loanblends (substitusi morfemis sekaligus pemasukan) itu sendiri yaitu terjadinya percampuran loanword atau kata yang dihasilkan baik dari penggantian maupun penamahan morfem. Dengan kata lain, beberapa bagian dari kata asing dipinjam sedangkan yang lain diganti dengan morfem yang sesuai dengan bahasa asli penutur.

\subsubsection{Loanshifts (Substitusi Morfemis tanpa Pemasukan)}

Dalam teori Haugen, Loanshifts diartikan sebagai kata-kata yang menunjukkan penggantian morfem tanpa adanya pemindahan atau kata-kata yang artinya dipindahkan tanpa adanya bentuk asing. Mereka dihasilkan dari peluasan makna dalam bahasa penerima sehingga berhubungan dengan kata dari bahasa sumber (peminjaman kata secara semantic atau perluasan semantic), atau pemindahan dari morfem yang tertata menjadi bahasa yang menerima (loan translation).

\section{METODE PENELITIAN}

Lokasi penelitian dilakukan di kampung Arab Singaraja dan Denpasar. Sumber data yang digunakan yaitu data berupa kuesioner dan daftar pertanyaan yang diajukan kepada komunitas Arab yang khususnya berumur 50 tahun keatas.Instrumen penelitian ini adalah kuisioner. Metode dan teknik pengumpulan data menggunakan metode simak dengan teknik yang digunakan yaitu teknik rekam, simak libat cakap dan catat dan teknik pancing. Metode dan teknik analisis data menggunakan metode kualitatif dan interpretasi. Metode dan teknik penyajian hasil analisis data menggunakan metode formal dan informal. 


\section{PEMBAHASAN}

Hasil analisis berupa analisis jenis-jenis loanwords (pemasukan morfemis tanpa substitusi), loanblends (substitusi morfemis sekaligus pemasukan), dan loanshifts (substitusi morfemis tanpa pemasukan) dalam bahasa Arab, yaitu:

\subsection{Loanwords (Pemasukan Morfemis tanpa Substitusi)}

Terdapat tujuh Loanwords (Pemasukan Morfemis tanpa Substitusi) ditemukan, yaitu:

\begin{tabular}{|c|c|c|c|c|}
\hline No. & Bentuk BA & BA Fonologi & Bentuk BI & BI Fonologi \\
\hline 1. & (abi) أبي (abi) & Abi: & Abi & /abi/ \\
\hline 2. & أمي (ummi) & Ummi: & Umi & /umi/ \\
\hline 3. & هدية (hadiyah) & Hadiyah & Hadiyah & /hadiyah/ \\
\hline 4. & تميد (tahmid) & Tahmid & Tahmid & /tahmid/ \\
\hline 5. & زوجة (zaujah) & Zaujah & Zaujah & /zaujah/ \\
\hline 6. & احسن (ahsan) & Ahsan & Ahsan & /ahsan/ \\
\hline
\end{tabular}

Tabel diatas merupakan bentuk loanword di komunitas Arab. Leksikon diatas dikatakan loanword karena tidak adanya morfemis yang masuk ke bahasa tersebut. Sehingga, dapat disimpulkan bahwa bahasa ini telah dipinjam oleh bahasa Indonesia dari bahasa Arab tanpa adanya perubahan baik dari system fonologinya maupun system morfologinya dan leksikon ini telah diseap secara sempurna dari bahasa aslinya.

\subsection{Loanblends (Substitusi Morfemis sekaligus Pemasukan)}

\begin{tabular}{|l|l|l|l|l|}
\hline No. & Bentuk BA & BA Fonologi & Bentuk BI & BI Fonologi \\
\hline 1. & رجل (rijal) & /ridzal/ & Rejal & /rejal/ \\
\hline 2. & يس (yasin) & Yasīn & Yasinan & /yasenan/ \\
\hline 3. & قهوة (qhahwah) & Qahwah & Gahwah & /gahwah/ \\
\hline 5. & بيت ( bait) & /xair/ & Ykher & /yxer/ \\
\hline 7. & Bayt & Bet & /bet/ \\
\hline
\end{tabular}

Dalam leksikon diatas, telah terjadi perubahan pada bahasa Arab, yaitu perubahan terhadap system fonologisnya. Apabila kita perhatikan, terdapat banyak pelesapan pada leksikonnya. Pada kata رجل (rijal) yang mempunyai arti laki-laki, disini telah mengalami perubahan pada 
bunyi vokalnya yaitu perubahan pada fonem /i/ menjadi /e/ yang nama kedua fonem ini samasama termasuk bunyi tegang. Kemudian kata يس (yasin) berubah menjadi /yasenan/ yang mana /yasenan/ mempunyai makna sedang melakukan kegiatan membaca yasin bersamasama. Leksikon ini mendapatkan tambahan suffix - an di akhir kalimatnya, selain itu juga terjadi perubahan pada bunyi /i/ menjadi /e/ yang mana keduanya termasuk sama sam bunyi tegang. Kata قهوة (qahwah) mempunyai arti kopi. Dalam tuturannya, kata ini telah mengalami perubahan, yaitu terjadi perubahan konsonan dari bunyi /q/ menjadi /g/. penyebabnya yaitu adanya pengaruh bunyi /a/ yang merupakan bunyi belakang dan rendah. Leksikon خير (khair) juga mengalami perubahan yaitu terjadi penambahan prefix /y/ di awal leksikonnya, selain itu juga terdapat perubahan fonologis yang terjadi, yaitu proses diftongisasi $/ \mathrm{kh} /$ menjadi $/ \mathrm{h} /$. Dan yang terakhir adalah kata بيت ( bait) yang bermakna rumah, dalam kata ini juga terjadi proses diftongisasi yaitu dari bunyi /ai/ menjadi /e/.

\subsection{Loanshifts (Substitusi Morfemis tanpa Pemasukan)}

Dalam loanshift ini, haugen membagi menjadi tiga bagian yaitu loan homonym yaitu pinjaman suatu kata yang memiliki makna yang berbed tetapi lafal atau ejaan yang sama. Kedua loan sinonim yaitu bentuk pinjaman yang berbeda bentuk tetapi mempunyai arti yang sama atau lebih sering dikenal dengan padanan kata. Dan yang terakhir yaitu loan translation yaitu antara bentuk kata dan maknanya sama.

\subsubsection{Loan Homonim}

\begin{tabular}{|l|l|l|l|l|l|l|}
\hline No. & Bentuk BA & $\begin{array}{l}\text { BA } \\
\text { Fonologi }\end{array}$ & Arti & Bentuk BI & BI Fonologi & Makna \\
\hline 1. & /hawi:/ & $\begin{array}{l}\text { Jatuh } \\
\text { Cinta }\end{array}$ & Hawi & /hawi/ & Pacaran \\
\hline 2. & $\begin{array}{l}\text { (hawi) } \\
\text { (fudhul) }\end{array}$ & /fud'u:1/ & Curiga & Fudhul & /fudul/ & Banyak tahu \\
\hline 3. & (syughul) & /Luyul/ & Kesibukan & Syughul & //ugul/ & Kerja \\
\hline
\end{tabular}


هوي (hawi), فضول (fudhul), شغل (syughul) memiliki bentuk yang sama dengan bahasa Indonesianya tetapi apabila mempunyai makna yang berbeda. Seperti kata هوي (hawi) dalam bahasa Arab diartikan sebagai jatuh cinta tetapi berbeda dengan arti di komunitas Arab. Rataفضول kata komunitas Arab mengartikannya pacaran bukan jatuh cinta. Kemudian kata (fudhul), dalam kamus bahasa Arab فضول (fudhul) diartikan sebagai curiga tetapi berbeda dengan komunitas Arab, mereka mengartikan فضول (fudhul) sebagai sok tahu atau banyak ingin tahu. Dan yang terakhir adalah شغل (syughul), dalam kamus bahasa Arab diartikan sebagai kesibukan, tetapi berbeda dengan yang diartikan oleh komunitas Arab mengartikan شغل (syughul) sebagai kerja.

\subsubsection{Loan Sinonim}

\begin{tabular}{|l|l|l|l|l|l|l|}
\hline No. & Bentuk BA & BA Fonologi & Arti & Bentuk BI & BI Fonologi & Makna \\
\hline 1. & عفو (áfwan) & / $\underline{\text { Safwan/ }}$ & Maaf & Allafu & /allafu/ & Maaf \\
\hline 2. & (qum) & /qum/ & Berdiri & Gum & /gum/ & Berdiri \\
\hline
\end{tabular}

Dua kata dalam table diatas dapat dikatakan sebagai loan sinonim, karena keduanya memiliki bentuk yang berbeda apabila dibandingkan dengan bahasa induk tetapi memiliki arti yang sama. عفوا (áfwan) apabila dalam tuturan komunitas Arab di Timur Tengah mereka lebih mengartikan عفوا (áfwan) sebagai tanda permintaan maaf atau sebagai ungkapan balasan untuk kata terima kasih, tetapi berbeda dengan komunitas Arab, mereka cenderung memakai Allafu sebagai bukti permintaan maaf mereka. Kedua pada kata قم (qum) apabila pada komunitas Arab di timur tengan mereka lebih mnegartikan dengan berdiri, tetapi berbeda dengan komunitas Arab lebih memakai Gum yang mempunyai makna yang sama dengan bahasa induknya. 


\subsubsection{Loan Translation}

\begin{tabular}{|l|l|l|l|l|l|l|}
\hline No. & Bentuk BA & BA Fonologi & Arti & Bentuk BI & BI Fonologi & Makna \\
\hline 1. & سوِّ (sawak) & /sawa:P/ & Sama & Sawak & /sawa?/ & Sama \\
\hline
\end{tabular}

Kata سوِّاء (sawak) memiliki makna sama, dalam tuturannya biasanya kata ini digunakan untuk mengungkapkan sesuatu hal yang sama. Dilihat dari segi bentuk maupun makna terlihat tidak ada yang berubah dari segi ejaan dan makna tetap sama, sehingga kata ini bisa dikatakan sebagai loan translation.

\section{SIMPULAN}

Berdasarkan hasil penelitian yang dilakukan, diperoleh beberapa simpulan yaitu,

1. Jenis language borrowing menurut Haugen dibagi menjadi tiga, yaitu loanwords (pemasukan morfemis tanpa substitusi), loanblends (substitusi morfemis sekaligus pemasukan), dan loanshifts (substitusi morfemis tanpa pemasukan).

2. Adapun kata yang termasuk loanword yaitu: أمي (abi), هدية (ummi), (hadiyah), , احسن (zaujah), (ahsan)

3. sedangkan loanshift terbagi menjadi tiga yaitu loan homonym, sinonimdan translation. Adapun contoh loan homonym yaitu: هوي (hawi), فضول (fudhul), شغل (syughul), loan sinonim yaitu: عفوا (áfwan), قم (qum) dan yang terakhir adalah loan translation, contohnya yaitu سوِّ (sawak)

4. Dan yang terakhir pinjaman yang termauk loanblend adalah رجل (rijal), يسل (yasin), قهوة (qahwah), بيت (bait) 


\section{DAFTAR PUSTAKA}

Chaer, A. dan Leoni A.2004.Sosiolinguistik Perkenalan Awal.Jakarta: Rineka Cipta.

Bakalla, M. H. 1984. Arabic Culture trought Its Language and Literature. London, Boston, Melbourne, dan Henly: Kegan Paul Internasional.

Beck, D., Yvonne L. Language lossand Linguistic Suicide: A Case Study from the Sierra Norte de Puebla. Mexico: University of Alberta

Haugen, Einer. 1950. "The Analysis of Linguistic Borrowing," dalam The Ecology of Language, Anwar S. Dil (penyunting). 1972. Standford: Stanford University Press.

Kridalaksana, Harimurti. 2009. Kamus Linguistik Edisi Keempat. Jakarta: PT Gramedia Pustaka Utama. 